\title{
COOL potatoes? Poland plans to introduce mandatory country of origin labelling for fresh potatoes
}

\author{
Ignacio CARREÑO and Lourdes MEDINA PÉREZ*
}

\begin{abstract}
On 14 November 2018, Poland's Ministry for Agriculture and Rural Development notified the European Commission (hereinafter, Commission) of its intention to introduce mandatory country of origin labelling (hereinafter, COOL) for potatoes on the basis of a Draft Regulation of the Minister for Agriculture and Rural Development amending the Regulation on the labelling of certain foodstuffs (hereinafter, Draft Regulation). ${ }^{1}$ Poland's notification is the most recent example of the continuously increasing number of EU Member States' measures on COOL for foodstuffs. While the EU already provides COOL requirements for fruits and vegetables in Regulation (EU) No 543/2011 of 7 June 2011 laying down detailed rules for the application of Council Regulation (EC) No 1234/2007 in respect of the fruit and vegetables and processed fruit and vegetables sectors ${ }^{2}$ (hereinafter, Regulation (EU) No 543/ 2011), they do not apply to fresh potatoes.
\end{abstract}

\section{BACKGROUND}

On 14 November 2018, Poland notified the Commission of its intention to introduce mandatory country of origin labelling for potatoes. Under point 7, "Notification Under Another Act", the notification refers to Directive 2000/13/EC relating to the labelling, presentation and advertising of foodstuffs as legal base. It appears that Poland intended a notification under Article 39(2) of Regulation (EU) No 1169/2011 of the European Parliament and of the Council of 25 October 2011 on the provision of food information to consumers $^{3}$ (hereinafter, FIR), which, in 2011, replaced Directive 2000/13/EC. Article 39(2) of the FIR provides that:

"[...] Member States may introduce measures concerning the mandatory indication of the country of origin or place of provenance of foods only where there is a proven link between

\footnotetext{
* Ignacio Carreño is a Senior Associate and Lourdes Medina Pérez is a Junior Lawyer at FratiniVergano - European Lawyers, a law firm with offices in Brussels and Singapore that specialises in international trade and food law. An earlier version of this report appeared in Trade Perspectives ${ }^{\odot}$, Issue No 22 of 30 November 2018, available at <www. fratinivergano.eu/en/trade-perspectives/ > (accessed 15 February 2019).

1 Communication from the Commission - TRIS/(2018) 03138, available at < ec.europa.eu/growth/tools-databases/ tris/nview.cfm?p=2018_562_EN_EN > (accessed 15 February 2019).

2 [2011] OJ L 157/1.

3 [2011] OJ L 304/18.
} 
certain qualities of the food and its origin or provenance. When notifying such measures to the Commission, Member States shall provide evidence that the majority of consumers attach significant value to the provision of that information".

The Draft Regulation submitted by Poland's Ministry for Agriculture and Rural Development proposes to introduce an obligation to provide information on the country of origin of potatoes at the place where they are sold or on the packaging. The labelling requirement would apply to fresh potatoes sold loose or packed, but not to processed potatoes. According to the regulatory impact assessment provided with the notification, the obligatory indication of potatoes' country of origin at the point of sale would meet the expectations of those consumers, who base their choice, inter alia, on the quality features of potatoes originating from different countries with varying climatic and soil conditions, farming techniques, and crop storage technology. The objective of the Draft Regulation "is to provide consumers with information on the country of origin of potatoes available in retail trade". In addition, the impact assessment states that the introduction of the obligation would contribute to aligning the requirements concerning the identification of the country of origin of potatoes with the COOL requirement for fresh fruits and vegetables covered by specific marketing standards at EU level by Regulation (EU) No $543 / 2011$.

The Draft Regulation intends to introduce the following measures to fresh potatoes, either sold loose or packed: (1) the indication of the country of origin, together with a representation of that country's flag, with the exception of products also labelled "with a 'Polish product' graphic mark"; (2) in retail areas, information concerning the country of origin and the representation of the flag thereof must be placed on a display placed in a visible position, directly accompanying the potatoes' presentation. The designation of the potatoes' country of origin must be presented in a font of a height not smaller than that used to present the designation of potatoes and the height of the representation of the flag of the country of origin of potatoes must not be lower than the height of the wording of the designation thereof; and (3) in the case of packed potatoes, COOL is required directly on the packaging. The Draft Regulation also indicates that the obligation would not apply to packed potatoes imported from any other EU Member State, Turkey, or marketed in a Member State of the European Free Trade Agreement (EFTA), which is a party to the Agreement on the European Economic Area. However, where the required information concerning their origin has not been provided on the labelling, such information must appear on a display placed in a visible position directly accompanying the presentation of those potatoes. Pursuant to the proposed provisions, the obligation to provide the information on the origin directly on the packaging of potatoes would be imposed on domestic Polish operators that package potatoes for consumer sales.

On 24 October 2018, Poland notified to the Commission a Regulation of the Minister for Agriculture and Rural Development amending the Regulation on labelling potato tubers other than seed potatoes. According to the notification, the labelling of potato tubers pursuant to Commission Directive 93/50/EEC should be expanded to include information on their country of origin. Such information should be provided where

4 Supra, note 1. 
potatoes are placed on the market by an operator other than the producer thereof and in the case of potatoes imported from third countries. ${ }^{5}$

Potatoes are one of the most important crops in the EU, growing even under high temperatures and in a wide variety of soils. Potatoes are, therefore, grown in all EU Member States. Over time, different varieties of potatoes have been created to satisfy the needs of the food chain. A number of broad categories of potatoes can be identified: early potatoes, main crop potatoes, seed potatoes and starch potatoes. Potatoes for human consumption (ie early and main crop potatoes) can be used as table potatoes, when they are supplied fresh to the consumer, or as raw material for the food processing industry. Potatoes for human consumption are one of the few agricultural products that are not covered by the EU's Common Market Organisation (hereinafter, CMO) in the context of the EU's Common Agricultural Policy (hereinafter, CAP), and which includes rules on COOL. Regulation (EU) No 1308/2013 of the European Parliament and of the Council of 17 December 2013 establishing a common organisation of the markets in agricultural products $^{6}$ (hereinafter, CMO Regulation), provides for internal market measures and a trade regime with third countries for a range of products. Since 2008, potato-growing areas in the EU are potentially eligible to receive direct payments. ${ }^{7}$ While EU potato producers may benefit from the CAP promotion and quality schemes, the Commission put forward proposals for a CMO for potatoes in 1992 and 1995, but no agreement was reached. ${ }^{8}$

In 2017, 62 million metric tonnes of potatoes were harvested in the EU, an increase of $12.4 \%$ compared to the average of the five previous years, and of $10.9 \%$ compared to 2016. This can be partially explained by the fact that the surface of land used for consumption potatoes (ie not seed potatoes), as well as the average yield are increasing in key EU Member States (ie Germany 18\%, Poland 15\%, France 13\%, Netherlands 12\%, UK $11 \%$ and Belgium 8\%), and in those EU Member States with an important processing industry, driven by exports of its products to third countries. ${ }^{9}$

As regards intra-EU trade in potatoes, about 6 million metric tonnes were exported to other EU markets, for a value of almost $€ 1.3$ billion. This involved mainly standard table (main crop) potatoes ( $68.3 \%$ of total intra-EU potato exports in value terms); seed potatoes accounted for $19.3 \%$ and early potatoes for $10.6 \%$, while starch potatoes made up the remaining $1.8 \%$. Three EU Member States accounted for almost two thirds of intra-EU exports in value terms: France $(28.5 \%)$, the Netherlands $(17.9 \%)$ and Germany $(17.1 \%)$, followed at a distance by Belgium (10.5\%). France and Germany primarily

\footnotetext{
5 Notification Number: 2018/537/PL (Poland), < ec.europa.eu/growth/tools-databases/tris/en/search/?trisaction = search.detail\&year $=2018 \&$ num $=537>$.

6 [2013] OJ L 347/671.

7 Potatoes, European Commission - Agriculture and Rural Development, available at <ec.europa.eu/agriculture/ potatoes_en $>$ (accessed 15 February 2019).

8 Potatoes for Human Consumption, European Commission (May 2010), available at < ec.europa.eu/agriculture/ sites/agriculture/files/potatoes/fact-sheet_en.pdf > (accessed 15 February 2019).

9 Under Council Regulation (EC) No 1782/2003 of 29 September 2003 establishing common rules for direct support schemes under the common agricultural policy and establishing certain support schemes for farmers, OJ 2003 L 270/1, as amended and later repealed by Regulation (EU) No 1307/2013 of the European Parliament and of the Council of 17 December 2013 establishing rules for direct payments to farmers under support schemes within the framework of the common agricultural policy, [2013] OJ L 347/608. Europatat Annual Report 2017, available at < europatat.eu/wpcontent/uploads/2018/05/Europatat_Annual_Report_2017-2018_web_.pdf > (accessed 15 February 2019).
} 
exported main crop potatoes (36.2\% and $20.4 \%$ respectively in value terms), while $59.1 \%$ (in value terms) of all seed potatoes traded within the EU came from the Netherlands. Italy and Spain were the most active intra-EU traders of early potatoes, both accounting for $22.8 \%$ each. $^{10}$

\section{EU RULES ON COOL}

There are already a number of food products that are subject to mandatory COOL in the EU, including some fruits and vegetables, ${ }^{11}$ beef, ${ }^{12}$ fish, ${ }^{13}$ olive oil ${ }^{14}$ and honey. ${ }^{15}$ Regarding meat, COOL was made mandatory for unprocessed fresh beef and beef products in the aftermath of the mad cow disease epidemic (ie Bovine spongiform encephalopathy, or BSE). ${ }^{16}$ It is also required for pre-packed poultry meat imported from third countries. ${ }^{17}$ In addition, the FIR requires that unprocessed fresh, chilled or frozen meat of swine, poultry, sheep and goats be accompanied by COOL. Specific rules under this regulation are set out in Commission Implementing Regulation No 1337/2013 of 13 December 2013. ${ }^{18}$ Likewise, Article 26(2)(a) of the FIR requires the indication of the country of origin or place of provenance where its omission could mislead the consumer as to the true country of origin or place of provenance of the final food in question, in particular if the information accompanying the food or the label as a whole would otherwise imply that the food has a different country of origin or place of provenance.

On 20 May 2015, the Commission adopted a Report to the European Parliament and Council regarding the mandatory indication of the country of origin or place of provenance for unprocessed foods, single ingredient products and ingredients that represent more than $50 \%$ of a food. ${ }^{19}$ The term "unprocessed foods" is defined in the FIR and refers to foodstuffs that have not undergone processing, and includes products that have been divided, parted, severed, sliced, boned, minced, skinned, ground, cut, cleaned, trimmed, husked, milled, chilled, frozen, deep-frozen or thawed. For example, flour, rice, and cut green vegetable salads are considered as unprocessed products. The FIR,

10 The EU potato sector, available at < europatat.eu/activities/the-eu-potato-sector/ > (accessed 15 February 2019).

11 Commission Regulation (EC) No 1580/2007 of 21 December 2007 laying down implementing rules of Council Regulations (EC) No 2200/96, (EC) No 2201/96 and (EC) No 1182/2007 in the fruit and vegetable sector, [2007] OJ L $350 / 1$.

12 Regulation (EC) No 1760/2000 of the European Parliament and of the Council of 17 July 2000 establishing a system for the identification and registration of bovine animals and regarding the labelling of beef and beef products, [2000] OJ L 204/1.

13 Council Regulation (EC) No 104/2000 of 17 December 1999 on the common organisation of the markets in fishery and aquaculture products, [2000] OJ L 17/22.

14 Commission Regulation (EC) No 1019/2002 of 13 June 2002 on marketing standards for olive oil, [2002] OJ L155/27.

15 Council Directive 2001/110/EC of 20 December 2001 relating to honey, [2002] OJ L 10/47.

16 Regulation (EC) No 1760/2000 of the European Parliament and of the Council of 17 July 2000 establishing a system for the identification and registration of bovine animals and regarding the labelling of beef and beef products, [2000] OJ L 204/1.

17 Art 5(4) of Commission Regulation (EC) No 543/2008 of 16 June 2008 laying down detailed rules for the application of Council Regulation (EC) No 1234/2007 as regards the marketing standards for poultry meat, [2008] OJ L $157 / 46$.

18 [2013] OJ L 335/19. For the legislative history, see I Carreño, "New EU rules on the country of origin labelling for meat of swine, sheep, goats and poultry" (2014) 2 EJRR 2013.

$19 \operatorname{COM}(2015) 204$ final. 
however, provides no definition of "single ingredient products", which for the purpose of the report are understood as products that contain only one ingredient or feedstock. Examples are sugar, tomato purée, vegetable oils of a single vegetable origin, frozen potato fries when no additive or salt has been added to these products. Fresh potatoes are neither "unprocessed foods" nor "single ingredient products" as defined above.

On 28 May 2018, the Commission adopted the long-awaited Commission Implementing Regulation (EU) 2018/775 laying down rules for the application of Article 26(3) of Regulation (EU) No 1169/2011 of the European Parliament and of the Council on the provision of food information to consumers, as regards the rules for indicating the country of origin or place of provenance of the primary ingredient of a food. ${ }^{20}$ Regulation 2018/775 applies in cases where the country of origin or the place of provenance of a food is given, voluntarily or mandatorily, by any means such as statements, pictorial presentation, symbols or terms, and where the country of origin or place of provenance is not the same as that of its primary ingredient, for example Belgian chocolate, as cocoa beans do not originate in Belgium.

\section{COOL AND THE POTATO SECTOR}

Pursuant to Article 76(1) of the CMO Regulation, fruit and vegetables that are intended to be sold fresh to the consumer, "may only be marketed if they are sound, fair and of marketable quality and if the country of origin is indicated". To harmonise the implementation of this provision, detailed rules are provided in the CMO Regulation and a general marketing standard is provided for most fresh fruit and vegetables. Regulation (EU) No 543/2011 then establishes specific marketing standards for ten food product groups (ie apples, citrus fruit, kiwifruit, peaches and nectarines, pears, strawberries, sweet peppers, table grapes and tomatoes as well as lettuces, curled-leaved and broadleaved endives). The number of specific standards for fruit and vegetables has been reduced from the previous 36. Further to the origin, such standards may, in particular, cover quality, categorisation, weight, size, packing, packaging, storage, transport, presentation and marketing. For fruits and vegetables figuring on the list of specific marketing standards, Regulation (EU) No 543/2011 provides detailed rules on the indication of the country of origin. Furthermore, the indication of the region, local place or district where the fruit or vegetable was grown may be indicated as well. Optionally, the district where the fruit or vegetable was grown, or national, regional or local place names, may also be indicated. Potatoes are neither covered by the specific standards, nor by the general marketing standard. According to a 2009 report by the Commission's Directorate General (hereinafter, DG) for Agriculture, potatoes are only covered in the $\mathrm{CMO}$ with respect to State aid rules, because the potato sector opposed the enforcement of a European quality standard for early and ware potatoes, as the potato production and the markets (eg presentation and packaging) were largely differentiated in all EU

20 OJ L 131, 29.5.2018, pp 8-11. 
Member States and the retail sector was defining different quality classes according to the wishes of the consumers. ${ }^{21}$

Indeed, the Commission's Green Paper on agricultural product quality: product standards, farming requirements and quality schemes provides that:

\begin{abstract}
"self-regulation has the advantage that policy is made, implemented and enforced by practitioners close to what is actually happening in the market. The procedures for drafting standards can be simpler and allow more flexibility and faster adjustment in a dynamic market environment. At the same time, the technical regulations are only applicable to those businesses that have undertaken to respecting them (also referred to as 'inter pares' arrangements, or arrangements between signatory parties). Examples of self-regulation may be found in the potato trade and fruit juice sector". ${ }^{22}$
\end{abstract}

Beyond EU legislation, the United Nations Economic Commission for Europe (hereinafter, UNECE), has developed more than 50 specific marketing standards for fresh fruit and vegetables (including the ten types covered by the specific EU marketing standards). ${ }^{23}$ This includes standards for potatoes, which require specifying the country of origin and, optionally, the district where the potatoes were grown, or national, regional or local place names. However, these standards only cover early and ware potatoes for human consumption ${ }^{24}$ (ie potatoes harvested before they are completely mature, marketed immediately after their harvesting, and whose skin can be easily removed without peeling).

The abovementioned DG Agriculture report notes that, in the potato sector, a sector without public EU standards, international UNECE quality standards for early and ware potatoes are used as a guideline for minimal standards for early and ware potatoes by the potato trade. Arguably, another reason for the lack of harmonised rules is the use of the EU system for Protected Designation of Origin (PDO) and Protected Geographical Indication (PGI) that apply to a number of EU potatoes. In order to inform and offer guarantees to consumers about the quality of the product, potato producers in Europe may apply for these quality schemes. Some examples of potatoes benefiting from this scheme are "Patata Kato Nevrokopiu" (PGI-Greece), "Pomme de terre de Merville" (PGI-France), "Pomme de terre de l'Île de Ré" (PDO-France), "Opperdoezer Ronde" (PDO-Netherlands), "Lapin Puikula" (PDO-Finland) and "Jersey Royal potatoes" (PDO - UK). Poland has registered PGIs and PDOs for some fruits and vegetables (eg "Truskawka kaszubska" strawberries, "Wiśnia nadwiślanka" cherries and some beans, apples and prunes). ${ }^{25}$ However, no such geographical indications have been registered yet for potatoes originating in Poland.

\footnotetext{
21 European Commission, DG Agriculture, Agricultural Product Quality Policy: Impact Assessment, Annex A(II): Marketing Standards, Version: 08-4-09, available at < ec.europa.eu/agriculture/quality/policy/com2009_234/ ia_annex_a2_en.pdf > (accessed 15 February 2019).

22 European Commission, Green Paper on agricultural product quality: product standards, farming requirements and quality schemes, COM/2008/0641 final, available at < eur-lex.europa.eu/legal-content/EN/TXT/? uri $=$ CELEX:52008DC0641 > (accessed 15 February 2019).

23 Available at < www.unece.org/trade/agr/standard/fresh/ffv-standardse.html > (accessed 15 February 2019).

24 UNECE Standard FFV-52 concerning the marketing and commercial quality control of early and ware potatoes, based on document ECE/TRADE/C/WP.7/2011/8.

25 See for all examples: European Commission DG Agriculture and Rural Development DOOR database, available at $<$ ec.europa.eu/agriculture/quality/door/list.html > (accessed 15 February 2019).
} 


\section{INTEREST OF POLISH AND OTHER EUROPEAN CONSUMERS ON THE COUNTRY OF ORIGIN OF FOOD}

The Brief Statement of Grounds that accompanied the notification of the Draft Regulation notes that the interest of domestic consumers to receive information on the country of origin of food was huge and supplementing the national provisions with a regulation concerning the origin of potatoes would provide consumers with information on potato origin comparable to that available in the case of fruits and vegetables covered by the CMO. Currently, given that EU provisions exist that provide an obligation to indicate the country of origin for certain categories of fresh fruits and vegetables, consumers comparing the labelling of potatoes with that of those fruits and vegetables perceived them as one product group and, thus, were confused by the absence of such information in the case of potatoes. An examination of production conditions in Poland, compared to those of other EU countries, carried out by the Plant Breeding and Acclimatisation Institute of the National Research Institute demonstrated that Poland possessed a number of specific conditions whose impact on the quality characteristics of potato tubers had been scientifically proven and made Polish potatoes distinguishable from ware potatoes produced in other EU Member States. ${ }^{26}$

The proposal set out by the provisions of the draft Regulation to augment written information about the origin of potatoes with an image of the country's flag embraces the current preference for visual information over written text. In a time of picture-based perception, in a society which deems obtaining information through image quicker, easier to understand and to remember, laying down an additional obligation to present a representation of the country's flag provides the consumer with a way to obtain information concerning the origin in the most accurate and legible way. ${ }^{27}$

There appears to be a trend in the EU that consumers demand mandatory declarations of origin for food products. On 19 September 2018, the Commission registered a European Citizens' Initiative (hereinafter, ECI) "Eat ORIGINal! Unmask your food". ${ }^{28}$ The ECI has the stated objective of imposing mandatory declarations of origin for all food products "in order to prevent fraud, protect public health and guarantee consumers' right to information". The Treaty on European Union (hereinafter, TEU) reinforces citizenship of the EU and provides that every citizen has the right to participate in the democratic life of the EU by way of the ECI (established in Articles 11(4) and 24 of the TEU). Such procedure affords citizens the possibility of directly approaching the Commission with a request inviting it to submit a proposal for a legal act similar to the right conferred on the European Parliament under Article 225 of the Treaty on the Functioning of the European Union (hereinafter, TFEU) and on the Council under Article 241 of the TFEU. In April 2012, Regulation (EU) No 211/2011 on the citizens' initiative entered into force, implementing the Treaty provisions. Once formally registered, an ECI allows one million citizens from at least a quarter of EU Member

\footnotetext{
26 Communication from the Commission - TRIS/(2018) 03138, available at < ec.europa.eu/growth/tools-databases/ tris/nview.cfm?p=2018_562_EN_EN > (accessed 15 February 2019).

27 Idem.

${ }^{28}$ C(2018) 6054 final, Commission Decision of 19 September 2018 on the proposed citizens' initiative entitled "Eat ORIGINal! Unmask your food".
} 
States to invite the Commission to propose a legal act in areas where the Commission has the power to do so. The conditions for admissibility, as foreseen by Regulation (EU) 211/ 2011, are that the proposed action does not manifestly fall outside the framework of the Commission's powers to submit a proposal for a legal act, that it is not manifestly abusive, frivolous or vexatious, and that it is not manifestly contrary to the values of the EU. The Commission's decision to register the ECI on imposing mandatory declarations of origin for all food products concerns only the legal admissibility of the initiative. At this stage, the Commission has not yet assessed the substance. The registration of the ECI on 19 September 2018 kicked off a one-year period, during which the ECI organisers may collect the required one million signatures of support. The organisers (ie the natural persons forming a citizens' committee responsible for the preparation of an ECI) of the ECI on mandatory origin labelling call on the Commission to impose mandatory declaration of origin for all food products in order to prevent frauds, protect public health and guarantee consumers' right to information ${ }^{29}$

\section{Legal situation in the EU and Perception of the Polish Regulation}

In addition to consumer demands, Poland's Draft Regulation reportedly responds to concerns expressed by Polish potato farmers regarding the necessity to ensure easier identification of the country of origin of potatoes at "every stage of the marketing". Earlier this year, the Polish Vegetable and Potato Union (ie Unia Warzywno Ziemniaczana) complained about the inability to sell Polish products on both domestic and foreign markets and that Polish stores were mainly supplied with foreign products. ${ }^{30}$

In 2017, Poland produced 9.8 million metric tonnes of potatoes. ${ }^{31}$ Regarding intra-EU trade, in 2017, Poland exported 22,521 metric tonnes of potatoes, fresh or chilled (ie HS 0701) and imported 116,605 metric tonnes. The most important EU Member States exporting potatoes to Poland are Germany (37,013 metric tonnes), the Netherlands (18,866 metric tonnes) and Greece (14,793 metric tonnes). France and Belgium exported 4,239 and 1,972 metric tonnes of potatoes to Poland, respectively. ${ }^{32}$

Furthermore, Poland's Ministry of Agriculture intends to introduce the definition of "early potato" in the Polish regulations, as potatoes imported from abroad are currently labelled as early potatoes in local stores. Allegedly, the use of such a name was misleading, as consumers then expected such products to have exceptional taste qualities. This would reduce the demand for new potatoes, consequently harming the market conditions for Polish producers. ${ }^{33}$

\footnotetext{
29 Available at <ec.europa.eu/citizens-initiative/public/initiatives/open/details/2018/000006 > (accessed 15 February 2019).

30 Fresh Plaza, Poland: Potatoes to be labelled with country of origin, Publication date: 15 May 2018, available at $<$ www.freshplaza.com/article/2194547/poland-potatoes-to-be-labelled-with-country-of-origin/> (accessed 15 February 2019) Source: <naszdziennik.pl/ekonomia-polska-wies/197131,ziemniaki-z-oznaczeniem-kraju-pochodzenia.html> (accessed 15 February 2019).

31 EU-28 potato production up by 9\% in 2017, FreshPlaza (November 2017), available at < www.freshplaza.com/ article/2185333/eu-28-potato-production-up-by-9-in-2017/> (accessed 15 February 2019).

32 Trade Helpdesk, European Commission, HS 0701 Potatoes, fresh or chilled (2017), available at < trade.ec.europa. eu/tradehelp/statistics > (accessed 15 February 2019).

33 Supra, note 30.
} 
The Draft Regulation notes that it aimed at providing better information to consumers regarding the quality of the potatoes. The Draft Regulation cites the results of a study conducted by the Plant Breeding and Acclimatisation Institute of the Polish National Research Institute, which found that Poland possesses several specific conditions that had an impact on the quality characteristics of potatoes, making Polish potatoes distinguishable from ware potatoes produced in other EU Member States. Under Article 39(2) of the FIR, EU Member States may introduce additional measures concerning mandatory COOL only where there is a proven link between certain qualities of the food and its origin or provenance. EU Member States must notify such measures and provide credible evidence to the Commission that the majority of consumers attach significant value to the provision of that information. Apart from the claimed wish of the consumer to know the origin or provenance of a product, a link must be established between the respective EU Member State of origin and a particular quality attribute. Such link must be established and corroborated by the respective EU Member State with respect to every single COOL scheme. Whether such a link between the quality and the origin of the Polish potatoes has been established in the information submitted by Poland, must be assessed by the Commission.

The labelling of potatoes with "Origin: Poland" and marked with a Polish flag, or any voluntary label with a "Polish product" graphic used as a synonym of "quality", could, arguably, also be misleading to consumers, and violate EU Internal Market rules. In this context, the French Council of State (ie the Conseil d'État), in a still pending preliminary question (Case C-485/18) to the Court of Justice of the EU relating to mandatory COOL for milk and milk used as ingredient of food, raised the question if the assessment of the conditions set out in Article 39 of the FIR presupposes that the qualities of a food are considered to be unique because of their origin or provenance or that the qualities are being guaranteed on the basis of the origin or provenance. ${ }^{34}$

National COOL requirements in single EU Member States may already restrict the free movement of goods, if they discriminate against businesses based in another EU Member State and thereby possibly violate Article 34 of the TFEU. Quantitative restrictions on imports and all measures having equivalent effect are prohibited between EU Member States. This essentially means that all trading rules that are enacted by EU Member States, which could hinder trade directly or indirectly, actually or potentially, fall under Article 34 of the TFEU and are thereby prohibited. ${ }^{35}$ Most importantly and troublesome, the national COOL measures appear to encourage local sourcing without regard to the detrimental impact that it may have on established supply chains, which transcend national, and sometimes even EU, borders. ${ }^{36}$ Although the national COOL requirements do not apply to products lawfully produced or marketed in another EU Member State, they may still have a detrimental effect on the EU internal market.

\footnotetext{
34 OJ 2018 C 352/25. Request for a preliminary ruling from the Conseil d'État (France) lodged on 24 July 2018, Groupe Lactalis v Premier ministre, Ministre de l'Agriculture et de l'Alimentation, Garde des Sceaux, Ministre de la Justice, Ministre de l'Économie et des Finances (Case C-485/18).

35 Case 8-74, Judgment of the Court of 11 July 1974, Procureur du Roi v Benoît and Gustave Dassonville. Reference for a preliminary ruling: Tribunal de première instance de Bruxelles - Belgium, ECR 1974-00837.

36 I Carreño and T Dolle “A Myriad of EU Member States' Measures on Mandatory Country of Origin Labelling (COOL) of Food Compromise the EU Internal Market” (2017) 4 EJRR 779.
} 
On 7 December 2018, the Standing Committee on Plants, Animals, Food and Feed (SCPAFF) - Section General Food Law, had an "exchange of views on a notification by Poland of a draft Regulation amending the Regulation on labelling potato tubers other than seed potatoes" on its agenda. ${ }^{37}$ Discussions in the SCPAFF on the Draft Polish Regulation on the labelling of certain foodstuffs, which includes COOL for fresh potatoes, will probably follow.

\section{Conclusion}

Although the mandatory COOL would not apply to products lawfully produced or marketed in another EU Member State, Turkey or any EFTA Member State, it might still have a detrimental effect on the EU internal market. Unlike other national COOL measures, the Draft Regulation does not foresee that potatoes may also be labelled as "origin: EU" or "origin: outside EU". Packaged potatoes produced in Germany and imported to Poland would also not require a label stating "Origin: Germany" and a graphic of the German flag. However, with or without the indication, it could be easily identified as a foreign product because it does not state "Origin: Poland" and show a graphic of the Polish flag, which could in turn lead to de facto discrimination as retailers and Polish consumers might prefer to buy only Polish origin products, perhaps independently of the quality of the product. National COOL measures appear to encourage local sourcing without regard to the detrimental impact that they may have on established supply chains that often transcend borders and might, thereby, restrict the free movement of goods, possibly violating Article 34 of the Treaty of the Functioning of the EU. The effect of mandatory origin labelling on all operators that are subject to the COOL requirements is an added cost for processors, which has consequences at all levels of the supply chain, from farmers to consumers. The piecemeal approach of national COOL measures does not do justice to the EU internal market. ${ }^{38}$

In developing mandatory origin labelling schemes, the EU's international trade obligations have to be taken into account. ${ }^{39}$ This applies to both the EU and its Member States, which are represented in the WTO by the Commission. In this respect, there are a number of lessons learnt from the US experience on mandatory COOL for certain agricultural commodities, which gave rise to a landmark WTO dispute between the US and Canada and triggered in 2008. ${ }^{40}$

The Draft Regulation states that the legislation would enter into force 30 days after its publication. Transitional rules would apply to packed potatoes that have been marked and placed on the market in line with the current provisions and may remain on the market until stocks run out, but no later than 31 December 2019. As the consultation is still ongoing, a spokesperson for the Commission stated that the Commission could not

\footnotetext{
37 Regarding the Notification 2018/537/PL, available at < ec.europa.eu/food/sites/food/files/safety/docs/regcom_gfl_20181207_agenda.pdf > (accessed 15 February 2019). Minutes of the meeting are yet to be published.

38 Supra, note 36.

39 See I Carreño, T Dolle and Y Rovnov, "Country of Origin Labelling on the Rise in EU Member States - An Analysis under EU law and the EU's International Trade Obligations" (2017) 2 EJRR 414.

40 United States - Certain Country of Origin Labelling (COOL) Requirements, Request for consultations by Canada, WTO Doc., WT/DS384/1, G/L/874, G/TBT/D/33, G/SPS/GEN/890, G/RO/D/6, 4 December 2008.
} 
comment or express its views on the Draft Regulation. All interested stakeholders should monitor the developments related to Poland's Draft Regulation on mandatory COOL for fresh potatoes.

In any case, these schemes would have to be consistent with EU law and WTO obligations so as to avoid potentially costly and destabilising litigation and legal uncertainty for economic operators. 